\title{
Positive Discourse Analysis of the Indonesian Government Spokesperson's Discursive Strategies during the Covid-19 Pandemic
}

\author{
Sultan $^{a}$ \\ sultan@unm.ac.id \\ Faculty of Languages and Literature, \\ Universitas Negeri Makassar, Indonesia \\ Muhammad Rapi \\ m.rapi@unm.ac.id \\ Graduate Program, \\ Universitas Negeri Makassar, Indonesia
}

\begin{abstract}
The Covid-19 pandemic that is sweeping across the globe has caused increased anxiety. Studies in linguistics have found a variety of language expressions that convey people's anxiety and fear. However, there are only a few researchers that studied the use of language used in communication by the government, to enhance the citizens' morale and help them recover from psychological distress from the Covid-19 pandemic. This study focused on investigating the discursive strategies used by the Indonesian government spokesperson at daily press conferences during the Covid-19 pandemic. This study employed the Positive Discourse Analysis (PDA) framework. A total of 28 recorded press conference sessions that lasted between 25-45 minutes were analyzed through the identification, interpretation, and explanation stages. Identification was carried out through careful reading of the transcription of the government spokesperson's speech to find out the discursive strategy used by the spokesperson. The interpretation was done by grouping similar quotes with the same themes, based on the context of the discourse. The explanation was done by explaining, in a macro way, the situational aspects and social contexts that provide the background for the texts' production and relating them to the pandemic. The results of the study showed that the spokesperson made use of nomination, predication, argumentation, perspectivization and intensification, and mitigation strategies to deliver information to the public. The entire discursive strategies are used to improve the public's optimism and build solidarity of the citizens as a moral force to face the pandemic. Suggestions for future research about analysis of pandemic discourse employed by the government include corpus analysis, power representation and framing.
\end{abstract}

Keywords: positive discourse analysis; Covid-19; discursive strategies; government communication; pandemic

\section{INTRODUCTION}

Since January 2020, the Covid-19 outbreak has been deemed a global health emergency by the World Health Organization (2020a). In Indonesia, the government responds to the crisis through regulations and actions. In just three months, from January to March 2020, as many as 15 regulations relating to the Covid-19 pandemic had been issued by the cross-section of governments (Djalante et al., 2020). The National Disaster Management Office in Indonesia (BNPB) was appointed to lead the acceleration of handling Covid-19. The military, police and religious organizations were involved in socialization, education and mitigation.

${ }^{a}$ Main \& corresponding author 
The Covid-19 pandemic has implications for various areas of life, thus creating interests among researchers from various disciplines, including medicine, psychology and linguistics. In linguistics, previous studies have revealed Covid-19 language phenomena from various perspectives. Nor Fariza and Adlyn Syahirah (2020) reviewed news reports about Covid-19 using a corpus-driven analysis. The results of this study generally indicate that collocates about Covid-19 reflect fear, anxiety, and uncertainty felt by the majority of Malaysians. Olimat (2020a) found that Jordanians used the language of dysphemism to reduce the negative effects of the outbreak and euphemisms to create more intimate conversations. The research finding highlights the existence of a specific form of communication for citizens who are affected by the pandemic situation. The Covid-19 study using the discourse approach carried out by Joharry and Turiman (2020) shows the views of Malaysians in their letters to editors, mostly calling the pandemic a challenge. The existence of psychological distress among the citizens concerning this outbreak based on these studies calls for further research about how the government communicate or deliver information about the pandemic to the public. The way in which the government portrays a pandemic event and influences citizens' behavior through the use of language is part of outbreak management that has yet to be revealed.

From the aspect of communication during the Covid-19 pandemic, Eriyanto and Ali (2020) show that the Indonesian government seeks to present discourse to dominate public conversations and conduct adjustments to mediate conflicting discourses. Another study conducted by Olimat (2020b) analyzed dysphemism in Trump's Covid-19 speeches. The findings revealed that the President of the USA used expressions that was more abusive and prone to humiliation, displeasure, and discrimination. In addition, the Covid-19 pandemic risks can be reduced more effectively if the government communicates the information clearly and leads the public to behave rationally and without fear (Kim \& Kreps, 2020). Because the government's ineffective communication during the Covid-19 pandemic can lead to confusion, misunderstanding and bring social impacts on the citizens as well as prolong the pandemic period (Kim \& Kreps, 2020). Studies by Eriyanto and Ali (2020) and Olimat (2020b) established that studies on how the government employed discursive strategies to inspire the citizens have not been researched, while Kim and Kreps's study (2020) demonstrated that research on the language used by the government in communication during the Covid-19 pandemic is timely, although studies such as Kim and Kreps (2020) and Rajandran (2020) have been carried out.

Rajandran's (2020) study about phrases used by the government and citizens to describe the Covid-19 pandemic situation revealed the use of war metaphors from the Malaysian and Singaporean Prime Ministers. War metaphors are used to frame aspects of the virus that include description, impact on various areas, actors' involvement, and government reactions. War scenarios can raise concerns about the threat and severity of Covid-19. However, the government also has an interest in boosting citizens' morale and maintaining the psychological state of the citizens. The use of a phrase that implies a persistent threat of a pandemic will bring stress and pressure. Therefore, inspirational and uplifting expressions such as "we certainly can!", "let's be heroes", "stay happy", and "take care of our hearts", are needed to maintain a positive psychological atmosphere.

In addition, studies on the Covid-19 discourse emphasized the individual and institutional efforts to build spirit through communication during the Covid-19 pandemic (Azizan et al., 2020; Jinshuang \& Rong, 2020). By studying Facebook posts about critical situations during the pandemic, Azizan et al. (2020) reported four positive themes expressed by the Malaysians that include religion, patriotism, call for heroism and public awareness. The study also revealed that linguistic strategies such as speech acts and figurative language contribute to creating public's positive reactions. Jinshuang and Rong (2020) found that the President of China, Xi Jinping, used lexical, syntax, and pragmatics strategies to show wisdom, power, teamwork and 
solidarity to fight the pandemic. Based on these two studies, it can be concluded that language plays a key role in raising hopes and giving inspiration at critical times.

The current study was focused on investigating the discursive strategies used by the Indonesian government's spokesperson. Texts that were used in the analysis were the speech texts delivered by the Indonesian government spokesperson at the official press conferences. During the coronavirus outbreak, the Indonesian government regularly delivers updates to the entire country through mass media. This study intends to highlight the language used by the government through the spokesperson in communicating about the Covid-19 pandemic to the citizens. Previous research shows that the pandemic has increased the intensity of anxiety of citizens through the publication of news in the mass media (Moghanibashi-Mansourieh, 2020; Roy et al., 2020). Press conferences hosted by the government may establish some form of ideology in shaping the citizens' perceptions. This is in line with the findings of Abbas (2020) who states that the news of Covid-19 has been used for ideological interests.

Research on discursive strategies relating to the Covid-19 pandemic discourse is necessary because this topic has not been explored. As described and discussed, past studies have only studied topics such as newspaper reports (Nor Fariza \& Adlyn Syahirah, 2020) and dysphemism (Olimat, 2020a, 2020b). The findings of Nor Fariza and Adlyn Syahirah (2020) indicated that the virus affected both economically and socially for Malaysia. However, some collocates described the government's full control over the situation. A different study conducted by Olimat (2020a) using a sociolinguistic approach showed that euphemism techniques were more dominant in Jordanians' daily Covid-19 conversations on Covid-19. Conversely, Olimat (2020b) reported that President Donald Trump empowered dysphemism to shape Americans' thoughts as to how they should fight to the virus. Studies by Nor Fariza and Adlyn Syahirah (2020) and Olimat (2020a, 2020b) established that studies on discursive strategies that are utilized by the government to communicate a pandemic situation to the public have yet to be carried out. Therefore, this study aimed to investigate the form of discursive strategies used by the Indonesian government spokesperson in press conference discourse. This study will provide insights into the study of language during pandemic situation. The results of this study can contribute to the linguistic studies about government communication during crisis situations.

This study used a PDA approach. The PDA framework has been used to uncover discursive practices that inspire national leaders' speech texts to wage resistance and encourage progressive social changes in Asia and Africa (Nartey, 2020; Nartey \& Ernanda, 2019). A study was conducted by Calle-Díaz (2019) to reconstruct peace in classroom discourse. Macgilchrist (2007) investigated strategies that were used to push marginal discourse into the mainstream news media, while Hughes (2018) analyzed progressive discourse and activist discourse in voicing the rights of the disabled groups who are interested in enhancing their cognitive development. Past studies have generally focused on emancipatory discourse from the perspective of nationalism, classroom discourse, disability discourse and media discourse.

PDA becomes a method to examine social-changes discourse to promote inspirational discursive practices. Inspirational discursive practices in the PDA context refers to encouragement, hope, and powerful messages delivered in difficult situations (Nartey, 2020; Nartey \& Ernanda, 2019). Two important studies by Nartey which employed PDA framework show that the speech texts delivered by two prominent revolutionary figures in the world, Soekarno and Nkrumah, contain language that is used to mobilize the masses, increase loyalty, strengthen groups, build communal identity, and promote emancipation discourse. For instance, President Soekarno used the words "evil" and "enemy" to refer to colonialism and imperialism to ignite the spirit of unity and solidarity among the Asian-African nations (Nartey \& Ernanda, 2019). In addition, Nkrumah made use of the phrases "new Africa", "fighting banner", "fight", "battle", and "struggle" to increase people's morale and boost their 
confidence to take action against (Nartey, 2018, 2020). Another application of PDA was demonstrated in Martin (2004), who found that reconciliation discourse in Australia was utilized to strengthen the voice of the oppressed groups, elicit empathy, and tell resistance stories that succeeded in awakening community solidarity.

This study intends to reveal the discursive strategies used by the government and expand the application of PDA for pandemic discourse analysis. The Covid-19 pandemic has been sweeping across the globe and thus has caused increased anxiety in world communities. As of November 6th, 2020, the World Health Organization (2020b) reported 48,196,862 Covid-19 confirmed cases and 1,226,813 deaths worldwide. In Indonesia, pandemic Covid-19 has infected 429,574 people and killed 14,442 people (World Health Organization, 2020c). The increase in Covid-19 cases and the increasing number of deaths increase citizens' anxiety. In this context, the analysis of discursive strategies used by the government will be useful in communicating problems relating to the Covid-19 pandemic to the citizens. This study was conducted to analyze how discursive strategies were used to motivate, encourage, and inspire people during the Covid-19 pandemic period. Specifically, it aimed to answer these questions:

1. What are the forms of discursive strategies used by the Indonesian government in official statements conveyed through daily press conferences during the Covid-19 pandemic?

2. Why are the discursive strategies used by the Indonesian government?

\section{POSITIVE DISCOURSE ANALYSIS}

One of the latest developments in the study of discourse that was first introduced by Martin (2004) is known as PDA. The term "positive" in this paper refers to the steps required to promote changes to make the world a better place; it is oriented not only to deconstruction, but also constructive social actions (Bartlett, 2012, 2017; Martin, 2004). Hughes (2018) identifies PDA as a concerned progressive discourse that transforms the current condition into a better condition that is hopeful and healing. This new approach operates to promote hope, inspiration, motivation, strength and resistance of the oppressed groups in society (Bartlett, 2012; Hughes, 2018; Nartey, 2020; Nartey \& Ernanda, 2019).

PDA is a new direction in Critical Discourse Analysis (CDA) that has been developed to have an impact on the social world although at an insignificant level (Macgilchrist, 2007). PDA is different from CDA that focuses on revealing the way discourse is manipulated, hegemony is hidden and ideology is naturalized by the dominant group (Bartlett, 2012). PDA is not a text celebration that is held based on particular ideological perspectives, but it constitutes an effort to identify discourse that has the potential to promote changes in society (Nartey, 2020). PDA is a constructive process that looks forward to improving the future, which is often associated with progress.

The main characteristic of PDA is reconstructions for social changes through resistance discourse. Resistance in PDA is perceived not only as a response to injustice but also as a social act that is oriented to trigger progressive social changes (Hughes, 2018). Moreover, Hughes argues that PDA theorizes about alternative directions that have not been realized and possible transformations for human mitigation. The understanding of social structures that support or limit resistance is a key factor in achieving PDA potentials (Hughes, 2018).

Within the Covid-19 pandemic context, resistance discourse is understood as a discourse that mobilizes and unchain people from pressures, anxiety, and any possible threats of the pandemic. The PDA framework is used as a basis for the study based on the fact that statements submitted by the government have the potential to change the behavior of the citizens. The anxiety generated by a pandemic has the potential to turn into optimism because of the 
government's discursive strategies that contain inspiring messages. For instance, effort to build self-confidence is carried out by state leaders as shown by the Chinese President Xi Jinping, who uses more positive and appreciative vocabulary to introduce effectiveness and experience in fighting epidemics (Jinshuang \& Rong, 2020). In this study, PDA was used to investigate how the government motivated and revived the citizens who felt threatened by Covid- 19 .

\section{DISCURSIVE STRATEGIES}

Discursive strategies refer to planned practices that are adapted to achieve a goal or represent a point of view or an ideology (Igwebuike, 2018; Reisigl \& Wodak, 2009). Discursive strategies can be understood as a social actor's effort to engineer reality in order to achieve purposes. The discursive strategy is a linguistic manifestation practiced to help or oppose certain political actions (Küçükali, 2015). Thus, the basis of the discursive strategy analysis is linguistic features. In the context of this research, discursive strategies mean actions taken by the government to promote resistance, revival, and struggle against Covid-19 (Nartey, 2020). Discursive strategies are used to direct attention, strengthen, and naturalize ideological attitudes towards a certain point of view (Kwauk, 2012). The depiction of an event by social actors is influenced by their interests, affiliations, preferences, and values (Carvalho, 2005)

Discursive strategies can be realized in discourse in various forms and empowered in various ways among the actors. Reisigl (2018) and Reisigl and Wodak (2009) identify the forms of discursive strategies that consist of nomination, predication, argumentation, perspectivization, and intensification and mitigation. Moreover, Carvalho $\left(2000 \underline{5}_{2} 2008\right)$ found discursive strategies in the form of analytical, evaluative, relational, positioning and framing strategies. These forms are described in detail in Table 1 and Table 2.

TABLE 1. Forms of discursive strategies by Reisigl and Wodak (2009)

\begin{tabular}{|c|c|c|}
\hline $\begin{array}{c}\text { Form of } \\
\text { Discursive } \\
\text { Strategies }\end{array}$ & Description & $\begin{array}{l}\text { Questions to Approach Discursive } \\
\text { Features }\end{array}$ \\
\hline Nomination & $\begin{array}{l}\text { The discursive construction of social actors, } \\
\text { objects, phenomena, events and actions. }\end{array}$ & $\begin{array}{l}\text { How are persons, objects, phenomena, } \\
\text { events, processes and actions named and } \\
\text { referred to linguistically in the discourse } \\
\text { in question? }\end{array}$ \\
\hline Predication & $\begin{array}{l}\text { Discursive characterization of social actors, } \\
\text { objects, phenomena, events processes and } \\
\text { actions }\end{array}$ & $\begin{array}{l}\text { What characteristics or qualities are } \\
\text { attributed to social actors, objects, } \\
\text { phenomena, events, processes and } \\
\text { actions mentioned in the discourse? }\end{array}$ \\
\hline Argumentation & $\begin{array}{l}\text { Persuading addressees of the validity of } \\
\text { specific claims of truth and normative } \\
\text { rightness }\end{array}$ & $\begin{array}{l}\text { What arguments are employed in } \\
\text { discourse? }\end{array}$ \\
\hline Perspectivization & $\begin{array}{l}\text { Positioning the speaker's or writer's point of } \\
\text { view and expressing involvement or distance }\end{array}$ & $\begin{array}{l}\text { From what perspective are these } \\
\text { nominations, attributions, arguments } \\
\text { expressed? }\end{array}$ \\
\hline $\begin{array}{l}\text { Intensification } \\
\text { and mitigation }\end{array}$ & $\begin{array}{l}\text { Modifying the illocutionary force of } \\
\text { utterances concerning their epistemic or } \\
\text { deontic status }\end{array}$ & $\begin{array}{l}\text { Are the respective utterances articulated } \\
\text { overtly, are they intensified or mitigated? }\end{array}$ \\
\hline
\end{tabular}


TABLE 2. Forms of discursive strategies by Carvalho $(2005,2008)$

\begin{tabular}{|c|c|c|}
\hline $\begin{array}{c}\text { Form of Discursive } \\
\text { Strategies } \\
\end{array}$ & Description & Questions to Approach Discursive Features \\
\hline Analytical & $\begin{array}{l}\text { Naming/ definition of an } \\
\text { event/phenomenon in } \\
\text { discourse }\end{array}$ & What it is or what it is about? \\
\hline Evaluative & $\begin{array}{l}\text { The value assigned to an } \\
\text { event/phenomenon }\end{array}$ & $\begin{array}{l}\text { What is the judgment of the value, importance, or } \\
\text { quality of something? }\end{array}$ \\
\hline Relational & $\begin{array}{l}\text { Relationships between actors } \\
\text { and other actors, issues, or } \\
\text { events in discourse }\end{array}$ & $\begin{array}{l}\text { How the social actor constitutes her/himself into } \\
\text { particular relations with others (be it social actors, } \\
\text { issues, or others? }\end{array}$ \\
\hline Positioning & $\begin{array}{l}\text { Self-placement strategy in a } \\
\text { conceptualization }\end{array}$ & $\begin{array}{l}\text { How the social actor attributes particular positions, } \\
\text { roles, or places to others? How are legitimacy and } \\
\text { politicization constructed? }\end{array}$ \\
\hline Framing & $\begin{array}{l}\text { The meaning of an event that } \\
\text { is displayed to the public }\end{array}$ & $\begin{array}{l}\text { What perspective or point of view is used to refer } \\
\text { to an event? }\end{array}$ \\
\hline
\end{tabular}

Based on the explanations about discursive strategies, data analysis in this study will be based on the perspective suggested by Reisigl (2018) and Reisigl and Wodak (2009). The discourse will consist of discourse produced by the Indonesian government's spokesperson.

\section{THE COVID-19 PANDEMIC DISCOURSE AND PUBLIC ANXIETY}

One of the major problems that arise during the pandemic is the management of public psychology. Updates on the coronavirus outbreak are continuously broadcasted by the mass media, thus, causing anxiety among the public. Exaggerated news reports and rapid information transmission through instant messages trigger a panic attack, stress, and anxiety (Dong \& Zheng, 2020). Roy et al. (2020) reported that the intensity of public anxiety was categorized high where $80 \%$ of people worldwide were busy thinking about Covid-19. In another study by Moghanibashi-Mansourieh (2020), an increased level of anxiety is observed among women, people who follow the news intensively, and the community members whose age ranged between 21 and 40 years old. These research findings indicate that the Covid-19 pandemic made the public depressed and anxious.

The PDA study on the pandemic discourse shows that there is an effort to foster power and solidarity among citizens. The findings from Azizan et al. (2020) show that through Facebook posts, citizens support each other by using the pronoun "we", collective expressions, or advice. The study emphasized the role of a strong sense of togetherness and solidarity, a strong national identity, values of patriotism and religion to unite and to fight the pandemic. The positive responses provided by society during a pandemic, according to the findings of Monahan et al., (2020), can improve mental and physical health specifically for adults.

During the pandemic, the Indonesian government has continuously provided information relating to Covid-19 through scheduled press conference sessions that are hosted by the government spokesperson. The press conferences are held to keep the people informed and updated about the pandemic recent development. The delivered information becomes part of the government's crisis communication that is trusted by the public. Public insecurity relating to the risks of the pandemic is noticed by the government, hence, the press conferences are utilized as a platform to promote feelings of resistance to public. In various press conferences, the government tried to increase the morale, spirit to fight, and solidarity of the people by delivering motivating expressions, sending positive messages and inviting the citizens to support each other. The Indonesian government's narration through Covid-19 is delivered to take the pressure off the people. This is based on the opinion of Öhman et al. 
(2016) who state that disaster discourse analysis aims not only to restore and repair self-image but also to bring changes to the current situation and society.

\section{METHODS}

This study was designed with PDA (Bartlett, 2012, 2017; Macgilchrist, 2007; Martin, 2004), orientation to reveal the discursive strategies used by the Indonesian government. PDA was chosen because it can be used as a tool to analyze social actions that bring progressive changes and transformations into society (Nartey, 2020). PDA is a framework that highlights the ideas of solidarity and empowerment. Agustín (2012) justifies PDA as an approach that emphasizes positive impacts that can be brought to civil society in creating social changes. Thus, PDA in this study was used to reveal the government's effort to communicate transformative discourse about the Covid-19 pandemic. The analysis was focused on the features of the discursive strategies utilized by the government's spokesperson.

The data for this study were collected from the press conference sessions hosted by the Indonesian government that become a reference for mass-media coverage and is awaited by the people every day. The daily press conferences are held to keep the people updated about Covid-19 pandemic in Indonesia. In the conferences, the statement of the government's towards the pandemic is delivered by $\mathrm{Mr}$ Achmad Yurianto as the Indonesian government spokesperson and the Indonesian Task Force for Covid-19 Rapid Response (Djalante et al., 2020). The press conference sessions were broadcasted live on the national TV stations. The data were obtained in the form of press conference recordings that were broadcasted from 17 March 2020 to 15 April 2020. During the period, the number of Covid-19 cases in Indonesia experienced a surge and thus increased public insecurity and anxiety. In just two months since the first coronavirus case was announced by the Indonesian President on March 2, 2020, the country has reached 1790 confirmed cases with 170 number of deaths (Djalante et al., 2020).

Twenty-eight recordings that lasted between 25-45 minutes each were analyzed using the PDA framework. Every recording contains information on the government policy relating to the government policies about the pandemic, updates on the number of Covid-19 cases under surveillance, the number of Covid-19 confirmed cases, the number of patients who died from the virus and who recovered. Data in the form of recordings were transcribed into writing using the Transcribe application. This application works by converting the press conference recordings into writings. The recordings were transferred into writings simply by pushing the "on" button. To ensure that the recording was fully transcribed, the researchers compared the audio recording and the transcription results. The parts that were missed by the application were transcribed manually. Next, the transcription results were read repeatedly to identify discursive strategies. Sentences or paragraphs that contain discursive strategies were tabulated into groups based on the similarity of features. For instance, the sentence "We can! Once more, we can!" was categorized into a slogan. All data relating to slogans that have similar features were categorized into a group. The selected data were translated into English by using interlingua translation technique, which involved transferring the entire text into English as the target language (Jacobson, 1992). The form and interpretation of the data were translated into English whereby the translated words chosen are as close as possible to the source language. However, certain words cannot be translated, for example, the concept of gotong-royong, which is a unique concept in Bahasa Indonesia was maintained to avoid misinterpretation.

Data analysis was performed in three stages, that were identification, interpretation, and explanation (Fairclough, 1989; Nartey, 2020). This analysis was employed because it was able to reveal the practices of discursive strategies that have ideological purposes. The discursive analysis guideline was employed in the identification process (Reisigl \& Wodak, 2009). The procedure for data analysis is described in Table 3. 
TABLE 3. Procedure for data analysis

\begin{tabular}{|c|c|c|c|c|}
\hline No & Phases & Description & Example of Data & Analysis \\
\hline 1 & Identification & $\begin{array}{l}\text { The researcher reads the } \\
\text { transcription carefully, examines } \\
\text { the linguistic aspects (discursive } \\
\text { features) that indicate the } \\
\text { discursive strategies of selected } \\
\text { data and highlights the discursive } \\
\text { features. } \\
\text { The elements examined include } \\
\text { choices of vocabulary, pronouns, } \\
\text { metaphors, sentences, etc. The } \\
\text { guiding question at this stage is } \\
\text { what linguistic elements represent } \\
\text { discursive strategies? }\end{array}$ & $\begin{array}{l}\text { We have to } \\
\text { believe that with } \\
\text { the spirit of } \\
\text { protecting each } \\
\text { other, we will win } \\
\text { the battle against } \\
\text { Covid-19. }\end{array}$ & $\begin{array}{l}\text { Identification of discursive } \\
\text { strategies: } \\
\text { the metaphor "win the } \\
\text { battle" }\end{array}$ \\
\hline 2 & Interpretation & $\begin{array}{l}\text { The researcher categorizes data } \\
\text { that have similarities in one } \\
\text { particular theme, provides a } \\
\text { description of the linguistic feature } \\
\text { and interprets the meaning. } \\
\text { Statements are interpreted } \\
\text { according to the context of the } \\
\text { discourse. }\end{array}$ & & $\begin{array}{l}\text { Through the metaphor "win } \\
\text { the battle" the Indonesian } \\
\text { government makes an } \\
\text { analogy between the effort to } \\
\text { fight the Covid-19 and a } \\
\text { battle. In a battle, people can } \\
\text { win or lose. Through the } \\
\text { metaphor, the government } \\
\text { attempts to convince the } \\
\text { citizens that they are going to } \\
\text { win the battle. }\end{array}$ \\
\hline 3 & Explanation & $\begin{array}{l}\text { The researcher explains in macro } \\
\text { analysis the situational aspects and } \\
\text { social context that underlie the text } \\
\text { production process and relates } \\
\text { them to the pandemic situation. }\end{array}$ & & $\begin{array}{l}\text { The government wants to } \\
\text { raise the spirit of citizens to } \\
\text { fight against the pandemic. } \\
\text { Through metaphors, the } \\
\text { Indonesian government } \\
\text { strives to increase the level } \\
\text { of confidence, enthusiasm } \\
\text { and confidence of citizens. } \\
\text { This was done because, } \\
\text { during the pandemic, there } \\
\text { was a concern and lack of } \\
\text { confidence among } \\
\text { Indonesians to survive from } \\
\text { the deadly attack of Covid- } \\
19 .\end{array}$ \\
\hline
\end{tabular}

\section{RESULTS AND DISCUSSION}

The results of the study are organized based on the five elements of discursive strategies that have been explained earlier in the previous section. Following is the description of the research findings.

\section{NOMINATION}

\section{FRAMING THE PANDEMIC WITH THE "WAR" METAPHOR}

The Indonesian government frames the Covid-19 pandemic as a battlefield. War is repeatedly used by the Indonesian government spokesperson as a metaphor to describe the situation. The word frequently appears in every official statement delivered by the spokesperson at the coronavirus press conference. Framing through the metaphor of 'war', therefore, transmits a 
psychological message to the citizens to consolidate their strength in facing critical/crucial situations and increase their awareness of threatening situations. The metaphor of 'war' is used to uplift the nation's morale in facing a crisis.

(1) The task force has been working for one month to ensure we can work together shoulder to shoulder, systematically, win the war against coronavirus together with all the strengths of our nation. (Gugus tugas sudah bekerja satu bulan demi memastikan kita untuk bisa secara bersinergi bahu membahu, sistematis, memenangkan peperangan melawan Covid-19 bersama-sama seluruh kekuatan bangsa kita).

(2) We must believe in the spirit of mutual protection, we will definitely win the war against Covid-19. (Kita harus meyakini bahwa dengan semangat saling melindungi, kita pasti akan memenangkan peperangan ini melawan Covid-19).

The metaphor "win the war" presented in excerpts (1) and (2) bring a message to the citizens that the government can control the situation. The belief in the government's victory over the war against Covid-19 will have a psychological impact on strengthening and fostering the citizens' optimism. This is done because, during the pandemic, there is increased concern and lack of confidence in Indonesia's ability to survive from the deadly Covid-19 attack. The metaphor "win the war" in the Covid-19 pandemic discourse is the government's strategy to foster national sentiment. The government desires to raise the citizens' spirit to fight against the pandemic. The metaphor of 'war' typically appears in national leaders' speeches that aims to awaken the spirit of nationalism of the citizens to face colonialism and imperialism (Nartey, 2018, 2020; Nartey \& Ernanda, 2019). In a crisis, the coronavirus outbreak is suggested as a threat that is equal to colonialism and imperialism.

The use of the metaphor "win the war" in the Covid-19 pandemic discourse aims to internalize the psychological power of struggle in a critical situation. Previous studies have shown that the metaphor of 'war' is often used to describe the relationship between patients with deadly diseases (Haller et al., 2019). Metaphors influence the way people think about a particular topic, leading their thoughts and behaviors (Thibodeau et al., 2017).

(3) The leader of the task force has the responsibility to control, hold the major command, in the war against Covid-19. This is explicitly stated in the Minister of Home Affairs circular letter. (Kepala gugus tugas memiliki tanggung jawab untuk mengendalikan, untuk memegang komando utama, dalam memerangi Covid-19. Ini sudah jelas dan tertuang dalam Surat Edaran Menteri dalam Negeri).

(4) Therefore, we hope that the command lead of the local government will encourage us to take care of all people, stay and be productive at home. (Karena itu kita berharap bahwa pimpinan komando dari kepala daerah ini akan memantapkan kita untuk menjaga semua agar masyarakat tetap berada di rumah, produktif dari rumahnya).

Excerpts (3) and (4) showed that the Indonesian government's effort to increase the resistance power against a crisis was made by using a metaphor which implies war leaders, to encourage the top-level leaders in the country. Through the metaphors of "main command" and "command leader", the leaders were described as individuals who controlled the situation in the front line in the war. The leaders play a role in making decisions and controlling the situation. Utilization of this metaphor aims to move leaders at their respective levels to take strategic roles and anticipatory steps in handling pandemics situation in Indonesia.

The metaphors "hold the major command", "war against", and "command lead" in excerpts (3) and (4) are considered delegation of authority from the supreme leader to the level 
leader as the commander in the war against Covid-19. On the other hand, these statements contain a powerful message that is delivered to the leaders/local government to take strategic decisions and steps to deal with the pandemic. On the other hand, the government wants to send a message to all citizens that the leaders have made their move. These statements have psychological content that seeks to inspire leaders at the lower levels to use their overall potential and strength. The government, through their statements, wants to emphasize leadership as an important aspect of the war against Covid-19. The use of the leadership metaphors implies that the Covid-19 problem must be solved with military strategies such as those that are used in a battlefield (Nartey 2018). To do that, the presence of a leader to carry out the strategies is key.

(5) Let us become a hero to protect ourselves, others, and the entire nation. (Mari kita menjadi pahlawan untuk melindungi diri, untuk melindungi orang lain, untuk melindungi seluruh bangsa ini).

(6) Let us, not only at the central level but also to the regional level.... Insha Allah, we will able to get through these difficult times and come out as the winner. (Mari bersama-sama bukan hanya di tingkat pusat, tapi terus sampai ke daerah.... Dengan cara seperti ini, insyaallah kita akan mampu melewati masa sulit dan kita akan bisa menjadi pemenangnya).

(7) We need to restore the position of society as the spearhead of the successful coronavirus prevention programs. (Kita harus kembali lagi menempatkan bahwa masyarakat adalah ujung tombak suksesnya pencegahan Covid-19 ini).

(8) May his soul now be at peace with God Almighty and according to their religion die as a warrior. (Semoga arwahnya kini tenang di sisi Tuhan Yang Maha Esa dan menurut agama mereka meninggal sebagai seorang pejuang yang sahid).

In excerpts (5)-(8), the Indonesian government utilized discursive strategies to foster the citizens' inspiration and motivation during the coronavirus outbreak. The positive psychological atmospheres containing encouragement messages are delivered on every occasion. The government attempts to boost the level of the citizens' confidence by giving them appreciation using metaphors. The labels are conceptualized in the coronavirus press conferences. These atmospheres are reflected through the use of metaphors "become a hero", "the winner", "warrior", and "spearhead".

The metaphors for heroism presented in the excerpts showed how the government's used discursive strategies to increase the citizens' participation in the war against the Covid19 pandemic. The invitation to "become a hero" and "be the winner" indicates the government's persuasion strategies to arouse the citizens' pride and enthusiasm to participate in the effort to deal with Covid-19. Heroes are honorable designations for people who are admired for their great service and sacrifice. A pandemic situation that has the potential to discourage and undermine the morality of citizens should be dealt with appropriate discursive strategies. Heroes are people who put themselves in danger to fight certain powers and show physical and mental courage in facing the possibility of injury and pain, even death (Öhman et al., 2016). Therefore, heroes are labeled as "the spearhead", that is known as a reliable weapon. The government would like to send a message to the citizens that they also play an important and strategic role in the coronavirus war. The expression " $a$ warrior" is not just a metaphor; it is religious. According to Gustafsson and Hommerberg (2016), war metaphors in health crisis discourse place the patient in a psychological status as a warrior and have two opposite sides, empowering and weakening. The findings of this study show that the Indonesian government aim for the rise of the citizens' motivation and heroism through war metaphors. 


\section{PREDICATION}

RAISING THE SPIRIT OF COLLECTIVISM AND PARALLELISM "PERSATUAN DAN KEBERSAMAAN (UNITY AND TOGETHERNESS)”

The Indonesian government through the spokesperson for Covid-19 uses discursive strategies to raise the spirit of collectivism. Collectivism is built on the use of parallelism, such as synergy, integration, unity, and togetherness that aim to awaken the spirit of collectivism.

(9) Hopefully, our hard work that has been synergized with the government, society, and everyone in the country can overcome the problems relating to the Covid-19 disease. We believe, we are optimistic, we can. (Mudah-mudahan upaya keras yang kita laksanakan secara sinergi bersama-sama pemerintah, bersama-sama masyarakat, bersama-sama siapa pun bisa menanggulangi permasalahan penyebaran penyakit Covid-19. Kami yakin, kami optimis, kita mampu.)

(10) Let us be together integrated so that all the government policies and efforts are fully supported. (Mari bersama-sama kita berintegrasi agar seluruh kebijakan pemerintah, seluruh usaha pemerintah dibantu dengan sepenuh hati.)

(11) We face it together, let us mutual cooperation, let us unite, let us protect each other so that we can fight against the coronavirus. (Kita hadapi bersama, mari bergotongroyong, mari bersatu, mari saling melindungi agar kita mampu melawan Covid-19 ini.)

(12) Let us participate more and more seriously because this is our problem. Just when together, we can deal with this problem. (Mari berpartisipasi lebih banyak dan lebih serius karena ini adalah masalah kita bersama. Hanya kita secara bersama-sama yang bisa menyelesaikan permasalahan ini)

(13) Know that we need mutual cooperation. By uniting, synergizing to protect each other from Covid-19, we can solve the problem successfully. (Ketahuilah bahwa kita membutuhkan kerja sama. Dengan bersatu, dengan bersinergi untuk menjaga agar Covid-19 ini kita bisa selesaikan dengan sebaik-baiknya).

Excerpts (9)-(13) showed that the Indonesian government gives top priority to promoting community togetherness in the face of a pandemic. The government assures that collectivism is a way to gain strength in the struggle against Covid-19. The parallelism that stands out in every statement includes (1) synergy with the government, society, and everyone in the country, (2) let us cooperate mutually, let us unite, let us protect each other, (3) by uniting, by synergizing indicates that the government wants to emphasize the importance of collectivism and unity. Features of parallelism employed in the press conference also aim to invite the citizens' attention to focus on the problem.

The statements that are delivered provide reasoning about the importance of collectivism as a solution and a force to face the crisis. The Indonesian government used the metaphor 'collectivism' to promote unity and togetherness among the Indonesian people. Unity discourse is commonly used to develop nationalism in the face of imperialism and colonialism, but in a pandemic situation, this strategy can also be used to deal with the outbreak. The target to be achieved is the growth of unity and togetherness.

\section{MANAGING PUBLIC EMOTIONS WITH PARALLELISM "POSITIVE ATTITUDE"}

The government makes use of parallelism "positive attitude" to maintain the spirit of the citizens. The positive emotions expressed by the Indonesian government through a spokesperson is a discursive strategy in times of crisis to lift the morale of a depressed country. The Covid-19 pandemic does not just strike physically but also triggers emotional distress. 
Positive emotions that show an aura of optimism, joy, and calm are needed to maintain the psychology of the citizens.

(14) Keep yourself happy. Maintain a distance between you and other people. Wear a mask. Do not touch your eyes, nose, and mouth before you wash your hand with soap and running water. (Jaga perasaan kita tetap bergembira. Jaga jarak. Pakai masker. Jangan menyentuh mata, hidung, mulut sebelum mencuci tangan pakai sabun dengan air).

(15) Let us together build optimism. Awake the optimism together. The (corona) virus keeps spreading. (Mari optimisme kita gali bersama. Kita bangkitkan bersama. Penyebaran masih terjadi).

(16) Get enough rest, eat nutritious food, be patient, be calm, rest, do regular exercise, and do not panic. These are key for all of us. (Istirahat yang cukup, makan makanan yang bergizi, sabar, tenang, istirahat, olahraga yang teratur, dan tidak panik. Ini menjadi kunci untuk kita semua).

(17) Brothers and sisters, we believe, we all together believe that we can go through this difficult time because we are willing to protect ourselves and our family sincerely. (Saudara-saudara sekalian, kami yakin, kita semua bersama-sama meyakini, kita bisa melalui masa-masa sulit ini karena kita bersedia dengan tulus dan ikhlas untuk melindungi diri sendiri, melindungi keluarga kita).

The excerpts demonstrated that the Indonesian government spokesperson offers strength in difficult times through positive lexical expressions. An invitation to stay happy (14) and be optimistic (15) aims to motivate the citizens to cope with anxiety and depression. To be patient, calm, not panicked, willing and sincere, such as presented in excerpts (16) and (17) are offered as the key formula to deal with the problem. Overall, the lexical expressions used by the Indonesian government spokesperson aim to raise the citizens' spirit and inspire them to be resilient in the face of diversity. This discursive strategy performs one function of positive discourse analysis that is to act as an inspirational artifact that offers a message of encouragement, hope, and strength (Nartey, 2020).

\section{ARGUMENTATION}

\section{ARGUMENTATION OF DEATH AS A COMPULSION}

In the pandemic Covid-19 discourse, the Indonesian government spokesperson used argumentation strategy to describe the deaths of the Covid-19 victims. Through the discursive strategies, the government wishes to send a message that the deaths of the patients are inevitable. Followings are the excerpts describing these strategies.

(18) We are deeply saddened by the passing of our brothers and sisters who were forced to die from this Covid-19 disease. We note that the number is evenly distributed in all provinces. (Kami sangat berduka dengan masih adanya saudara kita yang terpaksa harus meninggal karena penyakit Covid-19 ini. Kita mencatat jumlahnya sudah merata di semua provinsi).

(19) They are our brothers and sisters who are forced to fall in the battlefield carrying out their duty. (Mereka adalah saudara-saudara kita yang terpaksa harus gugur dalam melaksanakan tugasnya).

Excerpts (18) and (19) indicated the use of the clauses forced to die and forced to fall to explain the deaths of the Covid-19 patients. By using the expression "(be) forced to", the 
government sends a message that death is something that will happen to everyone; it is inevitable. Gavriely-Nuri (2018) mentions this strategy as naturalization, which is the disclosures of social objects as events independent of human choice or as an inevitable result of natural law. Naturalization strategy through the expression "(be) forced to" contains a message that the government has made every effort to prevent the death of the patients, but the situation is beyond the government's control.

The vocabulary choice "(be) forced to" is a form of terminological control in Covid19 discourse that is used by the government to broaden a perspective. Terminological control is needed to calm the people and to avoid them from panicking. This is in line with Alexander (2016) who points out that terminological control is an important feature of crisis communication. The government has the responsibility to keep the people calm and under control.

\section{PERSPECTIVIZATION}

CONTEXTUALIZATION OF THE CULTURAL PRACTICE "GOTONG ROYONG” (MUTUAL COOPERATION)

The crisis situation due to the Covid-19 outbreak prompted the Indonesian government to mobilize their power with the citizens. In various statements made at the press conference, the cultural practice "gotong-royong" (mutual assistance/cooperation) is contextualized to build solidarity. Gotong-royong is a distinctive cultural practice that is rooted in Indonesian's society. Gotong-royong was coined by Soekarno, the first President of Indonesia. It has been used since the pre-independence era and labeled as a national character that is the opposite of the individualistic character from the West (Budianta, 2019).

(20) Gotong-royong is the major value of our culture. And it needs to be maintained because our sense of gotong-royong is being tested. (Gotong-royong adalah nilai utama dari budaya kita. Dan ini yang akan terus kita pertahankan karena sifat gotong-royong inilah yang sekarang sedang diuji).

(21) Let us bergotong-royong (work together) and unite to fight against Covid-19. (Mari kita bergotong-royong dan bersatu untuk melawan Covid-19).

(22) We might no longer be silence, stop working on this huge task. Let us close ranks to bergotong-royong (work together) to solve this problem. (Kita tidak mungkin lagi untuk kemudian berdiam diri, tidak melanjutkan pekerjaan yang besar ini. Mari semakin merapatkan barisan untuk bergotong-royong menyelesaikan masalah ini).

The use of the cultural practice "gotong-royong" expressed the government's strategy to utilize a cultural value that symbolizes togetherness to drive national solidarity. Through the expression "gotong-royong is the major value of our culture" (20), (21), the government emphasizes the importance of a national cultural value in solving problems relating to Covid19. Gotong-royong is contextualized as the solution or the way out of the crisis (22). The three statements indicate the important role of gotong-royong in the war against coronavirus.

The cultural practice "gotong-royong" is contextualized by the government to calm down the citizen's fear. The government sends a message that coronavirus is a national problem that should be handled together. Gotong-royong is the Indonesian cultural practice that has synergizing effects and has been implanted in each of the individual's heart and society (Adha et al., 2019). Therefore, the Covid-19 victims will no longer feel alone because they received support from fellow citizens and there is a sense of common destiny among them. The contextualization of the cultural practice is used by the government as a form of moral support 
for the citizens to make them believe that they can get through the critical situation successfully.

The Indonesian government also utilized the brotherhood/sisterhood element in "gotong-royong" to nurture positive affect. The terms that are used refer to the emergence of compassion, solidarity and togetherness (Adha et al., 2019). The statements that are delivered at the press conference show the government's desires to tighten the social bond among citizens as the key factor in dealing with crises.

(23) We realize that this is actually the form of social tolerance that becomes part of Indonesian national identity. We will keep doing it and we believe that the society is with us in fighting against this problem. (Kami menyadari bahwa inilah sebenarnya bentuk toleransi social yang menjadi bagian dari jati diri bangsa Indonesia. Kita akan terus melakukan upaya ini dan kami yakin masyarakat akan bersama kita untuk menang menghadapi permasalahan ini).

(24) This is the time when we show our tenggang rasa (tolerance), gotong royong, and feeling of mutual protection as the Indonesian national identity. This is the time when we prove them. (Sudah pada saatnya tenggang rasa, gotong royong, dan saling melindungi yang merupakan jati diri bangsa Indonesia kita tunjukkan. Saat inilah kita buktikan).

(25) Let us set an example by showing humanity values, our solidarity is being tested. Our cooperation and tenggang rasa are being watched by the people around the world. (Mari kita menjadi teladan untuk menunjukkan nilai-nilai kemanusiaan, kekompakan kita sebagai bangsa sedang diuji. Kerja sama kita dan tenggang rasa kita sedang disaksikan oleh seluruh dunia).

The excerpts showed that the expressions "social tolerance" and "tenggang rasa" are used to encourage the citizens to act and play an active role. The government invites the citizens to be responsible in the fight against Covid-19. The government spokesperson's choice of language aims at touching the citizens' 'dignity'. By mentioning national value, the government wants the character and personality of the nation to be displayed. The expression "our solidarity is being tested" is a discursive strategy carried out to obtain support in the form of real actions. The government mentions these things as proof (24) and test (25).

In conclusion, cultural practice is constructed by the government to inspire and encourage citizen's participation in managing Covid-19 situation. The cultural practice "gotong-royong" is used to raise the citizens' awareness and awaken their morale. In a threatening pandemic situation, this strategy can be used to uplift the moral of a nation. The government's effort to use cultural practice as a discursive strategy is corroborated with the findings of Iuchi and Mutter (2020) who reveal that the communal work ethics in gotongroyong are highly functional in disaster situations and can increase the engagement and enthusiasm of the society. These findings are confirmed by Carney and Bennett (2014) who argue that rational-scientific approaches to pandemic management are not sufficient; instead, scientific and cultural interventions are needed in such situations.

\section{PROVIDING ENCOURAGEMENT THROUGH THE SLOGAN “WE CAN!”}

Providing encouragement through slogans is a prominent discursive strategy used by the Indonesian government in the Covid-19 discourse. These slogans contain motivation and are frequently repeated with the intention to arouse the citizens' motivation and spirit of struggle. The Indonesian government created slogans from short sentences that have persuasive function to inject moral strength and build confidence for the Indonesian citizens to get through the 
crises. These slogans are memorable, communicative and create impressive expressions in the citizens' minds (Newsome, 2002).

(26) Have faith. Have faith, have faith that Allah (God Almighty) will bless all of our efforts. We certainly can! We certainly can! (fight the coronavirus). (Yakinlah. Yakinlah, seyakin-yakinnya bahwa Allah akan meridhai usaha kita. Kita pasti bisa! Kita pasti bisa!)

(27) We believe that we can protect this country. All of this comes from us. Indonesia certainly can! (fight the coronavirus). (Kita yakin kita bisa melindungi bangsa ini. Semua berawal dari kita. Indonesia pasti bisa!)

(28) Protect the sick, protect the healthy, protect our family, protect our environment. Only then, we can be part of our national protection. We can! Once more, we can! (Lindungi yang sakit, lindungi yang sehat, lindungi keluarga, kita lindungi lingkungan kita. Maka, kita menjadi bagian yang kokoh dari lindungi bangsa kita. Kita bisa! Sekali lagi, kita bisa!)

(29) Brothers and sisters, we definitely can do this. We definitely can handle this. Salam tangguh, salam kemanusian! (Greetings for the tough, greetings for humanity!) (Saudara-saudara kita pasti bisa melaksanakan ini. Kita pasti mampu menangani ini. Salam tangguh, salam kemanusian!)

The excerpts (26)-(29) showed the government's efforts to arouse the citizens' optimism. The slogans "we certainly can", "we can", "Indonesia certainly can", and "salam tangguh, salam kemanusian" (greetings for the tough, greetings for humanity) are expressions that contain inspiration, hope, and power. The pronoun "we" is used as an effort to involve all the citizens to believe and to have the same view that they can go through the Covid-19 crisis successfully. The combined use of the slogans and repetition is a discursive strategy that aims to attract the citizens' attention and emphasize the importance of the slogans' content. This strategy is in line with the nature of a slogan that is to promote interest in and awareness of a particular problem or emphasize on a particular topic (Hartig, 2018).

The Indonesian government wishes to convey the information that can convince the citizens about the government's ability and the society to face the crisis. The government needs to convince the citizens that the fight against the coronavirus outbreak can be won. The slogans that are built from convincing, emotional, and credible messages will work effectively in persuasion (Newsome, 2002). The use of these slogans is a counter-discourse effort to reduce anxiety during the pandemic. The government needs to use this discursive strategy to maintain a positive atmosphere for the citizens' psychological feeling and to keep them calm.

\title{
INTENSIFICATION AND MITIGATION
}

\author{
RELYING ON GOD'S POWER
}

Religious discourse is one of the strategies employed by the Indonesian government to deal with the Covid-19 pandemic crisis. The spokesperson's statements at the press conference contain persuasion to rely on God's power. The government's statements are always encouraging and the spokesperson constantly mentions that God will help the people get out of this crisis. Indonesia is a country populated by Muslims, Christians, and other religions; hence, this provides the basis for the government's statements. This discursive strategy is acceptable since religiosity can have a positive impact on one's health and life satisfaction (Hayward and Elliott, 2014). Religious discourse is used by the Indonesian government to inject spirit, increase motivation, and boost the citizens' confidence in fighting against Covid19. 
(30) We believe that God Almighty will give us strength to face this difficult situation and we can get through this successfully. (Kita yakin bahwa Tuhan yang Maha Esa, Tuhan yang Maha Besar, akan memberikan kekuatan kepada kita untuk menghadapi masa sulit ini dan kita akan menyelesaikan dengan baik).

(31) We fight against Covid-19 together with the entire strength of our nation. Yakinlah (Believe) that God Almighty will protect us. And we can deal with this. (Kita melawan Covid-19 bersama-sama seluruh kekuatan bangsa kita. Yakinlah Tuhan Yang Maha Kuasa pasti akan melindungi kita. Dan pasti kita bisa mengatasinya).

(32) We can protect others. We can be a hero for our neighbors. Therefore, yakinlah (believe), believe with your heart that God Almighty will bless our efforts. (Kita bisa melindungi orang lain. Kita bisa menjadi pahlawan untuk tetangga kita. Oleh karena itu, yakinlah, yakinlah seyakin-yakinnya bahwa Allah akan meridhai usaha kita).

The use of the word "believe" and the particle -lah in "yakinlah" (believe) is an affirmation that the information and invitation delivered through the message are trustworthy. Through the word "yakin" (believe), the government attempts to instill confidence and encouragement in the citizens. In a depressed psychological condition, self-confidence needs to be boosted. Through the use of religious discourse, the government plays this role through the lexical choice "belief". According to Djalante et al. (2020), in the current pandemic situation of Covid-19, religion can serve as the solution to keep a calm mind and the feeling of safety. The government makes use of religious discourse to help the citizens overcome anxiety and fear towards life. Research by Jennings (2016) shows that religious discourse is an important factor that can determine an individual's behaviors and the formation of religious citizens' behaviors. Previous studies also confirm that religious appeals have implications for citizens' political attitudes and behavior (Albertson, 2011 \& 2015).

\section{CONCLUSION}

This study examined the discursive strategies represented by the Indonesian government's spokesperson at a press conference about Covid-19. The results of the study showed that the government made use of nomination, predication, argumentation, perspectivization, and intensification and mitigation in delivering information to the public. These discursive strategies were represented through language features in the form of metaphors, parallelism, slogans, choice of words, arguments and religious discourse. This study concludes that the government makes use of a variety of discursive strategies to strengthen the citizens' morale, raise the spirit of heroism, and provide encouragement. This is in line with the studies which reported that there is a feeling of fear from the threat of the virus (Nor Fariza and Adlyn Syahirah's (2020) and made the public depressed and anxious (Dong \& Zheng, 2020; Roy et al., 2020; Moghanibashi-Mansourieh, 2020).

This study contributes to linguistic studies of government communication during the Covid-19 pandemic. The study of discursive strategies using the PDA approach will complement studies about language and pandemic that were mostly focused on metaphors and corpus linguistics approach. The types discursive strategies used by the government revealed in this study can enrich PDA studies on Covid-19 discourse. This study also to contributes to PDA nationalism, classroom discourse, disability discourse and media, to pandemic discourse. The potential of PDA as a framework for analyzing the discursive strategies used by the government during the Covid-19 pandemic was confirmed in this study. The findings of the discursive strategies can be used by the government as a reference to focus and utilize discourse that can raise the spirit and hopes of the public in critical situations. 
The researchers recommend the application of PDA approach when analyzing the pandemics management discourse by governments in other countries. Different societal contexts between countries may be different with regards to the use of discursive strategies by the government. Ethnographic studies that measure the influence of government discursive strategies in delivering Covid-19 information to curb citizens' fear are needed in order to complement this study. Suggestions for future research about analysis of pandemic discourse employed by the government include corpus linguistics analysis, power representation and framing.

\section{REFERENCES}

Abbas, A. H. (2020). Politicizing the pandemic: A schemata analysis of Covid-19 news in two selected newspapers. International Journal for the Semiotics of Law-Revue Internationale de Sémiotique Juridique, July(3), 1-20. https://doi.org/10.1007/s11196020-09745-2

Adha, M. M., Budimansyah, D., Kartadinata, S., \& Sundawa, D. (2019). Emerging volunteerism for Indonesian millennial generation: Volunteer participation and responsibility. Journal of Human Behavior in the Social Environment, 29(4), 467-483. https://doi.org/10.1080/10911359.2018.1550459

Agustín, Ó. G. (2012). Enhancing solidarity: Discourses of voluntary organizations on immigration and integration in multicultural societies. Journal of Multicultural Discourses, 7(1), 81-97. https://doi.org/10.1080/17447143.2011.570344

Albertson, B. L. (2011). Religious appeals and implicit attitudes: Religious appeals and implicit attitudes. Political Psychology, 32(1), 109-130. https://doi.org/10.1111/j.14679221.2010.00793.x

Albertson, B. L. (2015). Dog-Whistle politics: Multivocal communication and religious appeals. Political Behavior, 37(1), 3-26. https://doi.org/10.1007/s11109-013-9265-x

Alexander, R. J. (2016). Shaping and misrepresenting public perceptions of ecological catastrophes: The BP gulf oil spill. Critical Approaches to Discourse Analysis across Disciplines, 7(1), 1-18. https://doi.org/10.5209/CLAC.53494

Azizan, M., Ismail, H. H., \& Qaiwer, S. N. (2020). Power and solidarity in positive Facebook postings amidst Covid-19 in Malaysia. Journal of Nusantara Studies (JONUS), 5(2), 329-364. https://doi.org/10.24200/jonus.vol5iss2pp329-364

Bartlett, T. (2012). Hybrid voices and collaborative change: Contextualising positive discourse analysis. Routledge.

Bartlett, T. (2017). Positive discourse analysis. In J. Flowerdew, \& J. E. Richardson (Eds.), The Routledge handbook of critical discourse studies (pp. 133-147). Routledge.

Budianta, M. (2019). Smart kampung: Doing cultural studies in the Global South. Communication and Critical/Cultural Studies, 16(3), 241-256. https://doi.org/10.1080/14791420.2019.1650194

Calle-Díaz, L. (2019). Possibilities of building peace through classroom discourse: A positive discourse analysis. Linguistics and Education, 54, 100762. https://doi.org/10.1016/j.linged.2019.100762

Carney, T., \& Bennett, B. (2014). Framing pandemic management: New governance, science or culture? Health Sociology Review, 23(2), 136-147. https://doi.org/10.1080/14461242.2014.11081968

Carvalho, A. (2005). Representing the politics of the greenhouse effect: Discursive strategies in the British media. Critical Discourse Studies, 2(1), 1-29. https://doi.org/10.1080/17405900500052143

Carvalho, A. (2008). Media(ted) discourse and society: Rethinking the framework of critical 
discourse analysis. Journalism Studies, 9(2), 161-177. https://doi.org/10.1080/14616700701848162

Djalante, R., Lassa, J., Setiamarga, D., Sudjatma, A., Indrawan, M., Haryanto, B., Mahfud, C., Sinapoy, M. S., Djalante, S., Rafliana, I., Gunawan, L. A., Surtiari, G. A. K., \& Warsilah, H. (2020). Review and analysis of current responses to Covid-19 in Indonesia: Period of January to March 2020. Progress in Disaster Science, 6, 100091. https://doi.org/10.1016/j.pdisas.2020.100091

Dong, M., \& Zheng, J. (2020). Letter to the editor: Headline stress disorder caused by Netnews during the outbreak of COVID-19. Health Expectations, 23(2), 259-260. https://doi.org/10.1111/hex.13055

Eriyanto, \& Ali, D. J. (2020). Discourse network of a public issue debate: A study on Covid19 cases in Indonesia. Jurnal Komunikasi: Malaysian Journal of Communication, 36(3), 209-227. https://doi.org/10.17576/JKMJC-2020-3603-13

Fairclough, N. (1989). Language and power. Longman.

Gavriely-Nuri, D. (2018). Cultural approach to CDA (CCDA): Theory and practice. In J. Flowerdew \& J. E. Richardson (Eds.), Routledge Handbook of Critical Discourse Studies (pp. 120-132). Routledge.

Gustafsson, A. W., \& Hommerberg, C. (2016). 'It is completely ok to give up a little sometimes': Metaphors and normality in swedish cancer talk. Círculo de Lingüistica Aplicada a La Comunicación, 67(0), 372-375. https://doi.org/10.5209/CLAC.53494

Haller, H., Vogel, H., Dobos, G., \& Ostermann, T. (2019). War metaphors in scientific cancer publications: A bibliometric meta-analysis. Advances in Integrative Medicine, 6, S73. https://doi.org/10.1016/j.aimed.2019.03.206

Hartig, F. (2018). Political slogans as instruments of international government communication-the case of China. The Journal of International Communication, 24(1), 115-137. https://doi.org/10.1080/13216597.2018.1444664

Hayward, R. D., \& Elliott, M. (2014). Cross-national analysis of the influence of cultural norms and government restrictions on the relationship between religion and well-being. Review of Religious Research, 56(1), 23-43. https://doi.org/10.1007/s13644-013-01350

Hughes, J. M. F. (2018). Progressing positive discourse analysis and/in critical discourse studies: Reconstructing resistance through progressive discourse analysis. Review of Communication, 18(3), 193-211. https://doi.org/10.1080/15358593.2018.1479880

Igwebuike, E. E. (2018). Discursive strategies and ideologies in selected newspaper reports on the Nigerian-Cameroonian Bakassi peninsula border conflict. Communication and the Public, 3(2), 151-168. https://doi.org/10.1177/2057047317748500

Iuchi, K., \& Mutter, J. (2020). Governing community relocation after major disasters: An analysis of three different approaches and its outcomes in Asia. Progress in Disaster Science, 6, 100071. https://doi.org/10.1016/j.pdisas.2020.100071

Jacobson, R. (1992). On Linguistic Aspects of Translation. In Theories of Translation: An Anthology Essay from Dryden to Derrida. The University of Chicago Press.

Jennings, J. T. (2016). Mixed reactions: How religious motivation explains responses to religious rhetoric in politics. Political Research Quarterly, 69(2), 295-308. https://doi.org/10.1177/1065912916636690

Jinshuang, L., \& Rong, L. (2020). A positive discourse analysis of diplomatic speech of President Xi in Covid-19. IETI Transactions on Social Sciences and Humanities, 8. https://doi.org/10.6896/IETITSSH.202006_8.0004

Joharry, S. A., \& Turiman, S. (2020). Examining Malaysian public letters to editor on Covid19 pandemic: A corpus-assisted discourse analysis. GEMA Online ${ }^{\circledR}$ Journal of Language Studies, 20(3), 242-260. https://doi.org/10.17576/gema-2020-2003-14 
Kim, D. K. D., \& Kreps, G. L. (2020). An analysis of government communication in the United States during the Covid-19 pandemic: Recommendations for effective government health risk communication. World Medical \& Health Policy, August, 1-15. https://doi.org/10.1002/wmh3.363

Küçükali, C. (2015). Discursive Strategies and Political Hegemony: The Turkish case (Vol. 64). John Benjamins Publishing Company. https://doi.org/10.1075/dapsac.64

Kwauk, C. T. (2012). Obesity and the healthy living apparatus: Discursive strategies and the struggle for power. Critical Discourse Studies, 9(1), 39-57. https://doi.org/10.1080/17405904.2011.632139

Macgilchrist, F. (2007). Positive discourse analysis: Contesting dominant discourses by reframing the issues. Círculo de Lingüística Aplicada a La Comunicación, 67(0), 372375. https://doi.org/10.5209/CLAC.53494

Martin, J. R. (2004). Positive discourse analysis: Solidarity and change. Revista Canaria de Estudios Ingleses, 49, 179-200.

Moghanibashi-Mansourieh, A. (2020). Assessing the anxiety level of Iranian general population during Covid-19 outbreak. Asian Journal of Psychiatry, 51, 102076. https://doi.org/10.1016/j.ajp.2020.102076

Monahan, C., Macdonald, J., Lytle, A., Apriceno, M., \& Levy, S. R. (2020). Covid-19 and ageism: How positive and negative responses impact older adults and society. American Psychologist, 75(7), 887-896. https://doi.org/10.1037/amp0000699

Nartey, M. (2018). 'I shall prosecute a ruthless war on these monsters ... ': A critical metaphor analysis of discourse of resistance in the rhetoric of Kwame Nkrumah. Critical Discourse Studies, 16(2), 113-130. https://doi.org/10.1080/17405904.2018.1535987

Nartey, M. (2020). Voice, agency and identity: A positive discourse analysis of 'resistance' in the rhetoric of Kwame Nkrumah. Language and Intercultural Communication, 20(2), 193-205. https://doi.org/10.1080/14708477.2020.1722686

Nartey, M., \& Ernanda. (2019). Formulating emancipatory discourses and reconstructing resistance: A positive discourse analysis of Sukarno's speech at the first Afro-Asian conference. Critical Discourse Studies, 17(1), 22-38. https://doi.org/10.1080/17405904.2019.1617758

Newsome, C. (2002). The use of slogans in political rhetoric. The Corinthian, 4(1), 21-35.

Nor Fariza, M. N., \& Adlyn Syahirah, Z. (2020). Corpus driven analysis of news reports about Covid-19 in a Malaysian online newspaper. GEMA Online ${ }^{\circledR}$ Journal of Language Studies, 20(3), 199-220. https://doi.org/10.17576/gema-2020-2003-12

Öhman, S., Giritli Nygren, K., \& Olofsson, A. (2016). The (un)intended consequences of crisis communication in news media: A critical analysis. Critical Discourse Studies, 13(5), 515-530. https://doi.org/10.1080/17405904.2016.1174138

Olimat, S. N. (2020a). Covid-19 Pandemic: Euphemism and dysphemism in Jordanian Arabic. GEMA Online ${ }^{\circledR}$ Journal of Language Studies, 20(3), 268-290. https://doi.org/10.17576/gema-2020-2003-16

Olimat, S. N. (2020b). Words as powerful weapons: Dysphemism in Trump's Covid-19 speeches. 3L The Southeast Asian Journal of English Language Studies, 26(3), 17-29. https://doi.org/10.17576/3L-2020-2603-02

Rajandran, K. (2020). 'A Long Battle Ahead': Malaysian and Singaporean Prime Ministers employ war metaphors for Covid-19. GEMA Online ${ }^{\circledR}$ Journal of Language Studies, 20(3), 261-267. https://doi.org/10.17576/gema-2020-2003-15

Reisigl, M. (2018). The Routledge handbook of critical discourse studies. In J. Flowerdew \& J. E. Richardson (Eds.), The Routledge Handbook of Critical Discourse Studies (pp. 44-59). Routledge.

Reisigl, M., \& Wodak, R. (2009). The discourse-historical approach (DHA). In IR. Wodak \& 
M. Meyer (Eds.), Methods for critical discourse analysis (pp. 87-121). SAGE Publication, Inc.

Roy, D., Tripathy, S., Kar, S. K., Sharma, N., Verma, S. K., \& Kaushal, V. (2020). Study of knowledge, attitude, anxiety \& perceived mental healthcare need in Indian population during COVID-19 pandemic. Asian Journal of Psychiatry, 51, 102083. https://doi.org/10.1016/j.ajp.2020.102083

Thibodeau, P. H., Hendricks, R. K., \& Boroditsky, L. (2017). How linguistic metaphor scaffolds reasoning. Trends in Cognitive Sciences, 21(11), 852-863. https://doi.org/10.1016/j.tics.2017.07.001

World Health Organization. (2020a). Statement on the second meeting of the International Health Regulations (2005) Emergency Committee regarding the outbreak of novel coronavirus (2019-nCoV) (online). Retrieved from https://www.who.int/news/item/3001-2020

World Health Organization. (2020b). WHO Coronavirus Disease (Covid-19) dashboard (online). Retrieved from https://covid19.who.int.

World Health Organization. (2020c). WHO Coronavirus Disease (cOVID-19) dashboard: Indonesia (online). Retreived from https://covid19.who.int/region/searo/country/id. 


\section{APPENDIX}

\section{EXAMPLE OF THE INDONESIAN GOVERNMENT SPOKESPERSON'S PRESS CONFERENCE TRANSCRIPT}

English
Ladies and Gentlemen. Good afternoon.
Today, we are going to deliver some news regarding
the handling of Covid-19 that we have done together
and that has involved all walks of life, including the
central and local governments working together in
synergy to deal with this Covid-9 pandemic....
We hold the key to the success of overcoming
Covid-19. Therefore, maintain a distance of more than
two meters when communicating with anyone, wash
your hands with soap, educate this, pass on this
information to our neighbors, to our families so that
they can comply with everything. Then try to stay safe
and productive at home. We believe, we all love our
family. Therefore, it is better to postpone the long trip
to your hometown because this virus will transmit
along with the movement of the infected person.
Humans brought it, therefore we can assure you that
the safest fortress that can protect us from this virus
attack is our home. Let's be a hero. Protect yourself,
protect your family, protect your neighbors. So this is
the most correct way to protect our nation. I believe I
am optimistic that, together, we will be able to do this.
Indonesia surely can....

\section{April 2, 2020}

Ladies and Gentlemen, on this occasion, we would like to say a few things; First of all, we are very proud and amazed by the initiative of all Indonesians to ensure that all of their friends, all their families, all of their colleagues stay at home. We've also seen tons of virtual charity concerts, inspiring and entertaining videos and short video messages on social media. Thank you for the efforts of the community who are not only obedient and disciplined for themselves but also willing to encourage their friends to be obedient and disciplined in carrying out the rules together. Thank you, know that we all need to work together, in synergy, to solve this Covid-19 pandemic at our best.

What we need to work on together is the issue of the health workers in the infected area. Therefore, what we need to do is to keep looking for the positive cases in the community because it will allow us to identify the infected people, isolate and put them in quarantine to prevent virus transmission....

\section{April 14, 2020}

Good afternoon, Ladies and Gentlemen. On this occasion, I would like to inform you again about the update of today's handling of the Covid-19 pandemic. This time, we are going to deliver some things relating to the pandemic. First of all, we would
31 Maret 2020

Saudara sekalian. Selamat sore, pada hari ini kami akan menyampaikan beberapa hal terkait dengan perkembangan penanganan Covid-19 yang telah bersama-sama kita laksanakan dan melibatkan semua lapisan masyarakat, baik pemerintah pusat, pemerintah daerah yang kemudian secara sinergi melaksanakan kegiatan bersama untuk menanggulangi Covid-19 ini....

Kunci keberhasilan penanggulangan Covid-19 ini terletak pada kita. Oleh karena itu, menjaga jarak dalam berkomunikasi dengan siapa pun lebih dari dua meter. Biasakan mencuci tangan dengan menggunakan sabun, edukasikan ini, sampaikan ini kepada tetangga kita, kepada keluarga kita agar bisa mematuhi semuanya. Kemudian, upayakan tetap aman dan produktif di rumah. Kami yakin, kita semuanya sayang dengan keluarga kita. Oleh karena itu, sebaiknya tunda dulu untuk melakukan perjalanan panjang ke kampung halaman karena virus ini akan berpindah bersamaan dengan pergerakan orang yang terinfeksi. Manusialah yang membawanya. Oleh karena itu, kita yakinkan bahwa benteng yang paling aman untuk serangan virus ini adalah rumah kita. Mari jadilah pahlawan! Lindungi diri Anda, lindungi keluarga Anda, lindungi tetangga Anda! Maka inilah cara yang paling benar untuk melindungi bangsa kita. Saya yakin, saya optimis, kita bersama-sama akan mampu melaksanakan ini. Indonesia pasti bisa....

\section{April 2020}

Saudara sekalian, pada kesempatan hari ini, akan kami sampaikan beberapa hal. Yang pertama, kami sangat bangga dan kagum dengan inisiatif seluruh masyarakat Indonesia untuk memastikan bahwa seluruh teman-temannya, seluruh keluarganya, seluruh koleganya untuk tetap tinggal di rumah. Ini menjadi sesuatu yang sangat penting. Kita juga sudah melihat di media sosial banyak sekali konser-konser amal virtual, kemudian video yang inspiratif juga menghibur pesan, video singkat dan terima kasih atas upaya masyarakat yang bukan hanya patuh dan disiplin untuk dirinya saja, tetapi juga menyemangati agar patuh dan disiplin melakukannya bersama-sama. Terima kasih, ketahuilah bahwa kita sama-sama membutuhkan kerja sama dengan bersatu dengan bersinergi untuk menjaga agar Covid-19 ini kita bisa selesaikan dengan sebaik-baiknya.

Pekerjaan bersama kita salah satunya adalah tenaga kesehatan yang berada di daerah yang telah terinfeksi. Oleh karena itu, tetap yang harus kita lakukan adalah mencari dan mencari kasus positif di tengah masyarakat karena dengan kita temukan kasus 
like to deliver our deepest sympathies to those who had to die because of the Covid-19 disease. We note that the number of deaths is evenly distributed in all provinces and we are also confident that this will continue to happen in the future. It will bring various impacts both on the family left by the deceased and on all of us. Therefore, it is a very deep concern for the country and it is no longer possible for us to remain silent and not to continue this huge task. Let's close ranks to bergotong-royong (work together) to solve this problem.... positif di tengah masyarakat maka kita bisa
melakukan isolasi kemudian kita bisa melakukan
karantina agar tidak terjadi penularan ke orang lain....

14 April 2020

Selamat sore, Saudara sekalian, pada kesempatan hari ini, saya akan menyampaikan kembali update yang kita dapatkan dari kinerja selama satu hari ini terkait dengan penanggulangan pandemi Covid-19. Kali ini, kami akan sampaikan beberapa hal. Yang pertama, kami sangat berduka dengan masih adanya saudara-saudara kita yang terpaksa harus meninggal karena penyakit Covid-19 ini. Kita mencatat jumlahnya sudah merata di semua provinsi ada dan kita juga akan meyakini bahwa ini masih akan terus terjadi. Ini akan mengakibatkan berbagai macam dampak, baik pada keluarga yang ditinggalkan atau kepada kita semuanya. Oleh karena itu, ini keprihatinan yang sangat mendalam bagi negara dan kita tidak mungkin lagi untuk kemudian berdiam diri tidak melanjutkan pekerjaan yang besar ini. Mari semakin merapatkan barisan untuk bergotong-royong menyelesaikan masalah ini....

\footnotetext{
ABOUT THE AUTHORS

Sultan is a Senior Lecturer at the Faculty of Languages and Literature, Universitas Negeri Makassar, Indonesia. His current research includes critical discourse analysis, critical reading, and teaching reading.

Muhammad Rapi is a Professor at the Graduate Program, Universitas Negeri Makassar, Indonesia. His areas of interest are leadership in ancient manuscripts, postcolonial studies, and critical discourse analysis.
} 